\title{
Integration of Kinesthetic Approaches in the Core Academic Subjects: A Compendium
}

\author{
Joey D. Jabonete ${ }^{\mathrm{a}}$, Cresencio L. Mejarito ${ }^{\mathrm{b}}$ \\ joey.jabonite@deped.gov.ph \\ PE Instructor, Lourdes National High School, DepEd Panglao, Bohol, 6340, Philippines \\ PE Instructor \& Athletic Coordinator, University of the Visayas, Cebu City, 6000, Philippines
}

\begin{abstract}
Kinesthetic mode of learning involves the use of movements and other kinesthetic sense which provides an authentic learning experience to actively engage students in a lesson and create connections with real-world situations. As educators adopt new ways of teaching in this time of pandemic, the integration of kinesthetic approaches in teaching and learning can positively influence students' learning experience. It is in this direction that this study is conceived with the aim to determine the integration of kinesthetic approaches in the teaching of the core academic subjects in the prepared modular distance learning kit for the junior high students during the first quarter of S.Y. 2020-2021. Quantitative approach is used in this research and the selflearning modules are the primary sources of data. The following findings were revealed: (1) The extent of integration of kinesthetic approaches in the core academic subjects: English, Math, Science and Social Studies was seldom integrated; (2) There are no preferred kinesthetic approaches integrated into the modules of the core academic subjects; and (3) kinesthetic approaches are integrated in the activity part of the module. Moreover, the study aimed to develop a compendium of kinesthetic approaches that can be integrated into the learning modules to keep students actively engage with learning materials and at the same time, fulfilling their physical and cognitive growths.
\end{abstract}

Keywords: Kinesthetic approaches; Kinesthetic teaching; Kinesthetic learning; Printed Modular Instruction

\section{Introduction}

As the world is shaken by the wrath of the COVID 19 pandemic, it creates a massive shift to education that changes the landscape of the global education system and has given rise to a new normal mode of teaching. The Department of Education has been working hard on the transition from the traditional "faceto-face" learning to the so-called blended learning to ensure that learning opportunities are offered to learners securely during these trying times.

Blended learning is a combination of learning approach of online distant learning, for those who have access to internet and in-person distribution of printed learning materials to the learners' respective homes via barangay, for those who have no internet connectivity and interactive facilities in their homes. 
However, most students prefer to use the printed learning material "modular" distance learning as a mode of instruction (DepEd, Learner Enrollment and Survey Form). These printed materials are intended for students to learn a specific unit or lesson wherein students actively engage with the instructional material rather than passively read the instructional material as embodied in the DepEd Bohol D.M. No. 188, S. 2020.

As educators adopt to this "new normal" of teaching with the use of printed materials or what we called self-learning modules, the traditional arena for academic engagement has been diminished. It creates new challenges over ways in keeping students actively engaged within the lessons in fulfilling their physical and cognitive growths amid this pandemic. In addition to the detriment, the use of self-made learning modules has the potential to increase the number of times children are sedentary. It is even more imperative to consider how this mode of learning will affect a student's physical activity levels and well-being and interest in learning to improve educational outcomes.

In this light, a compendium of kinesthetic approaches that can be integrated into the learning modules can be an avenue to keep students physically and academically engaged to improve academic performance amid pandemic. Kinesthetic modality involves the use of movements and other kinesthetic senses that provides an authentic learning experience to actively engage students in a lesson, create connections with real-world situations, and make learning more enjoyable and fun. Research has shown that engaging in movement activities could help develop students' interest and concentration in learning (Lengel \& Kuczala, 2010). Students who had received movement instructions are most likely better learners than those who are idle (Barker, 2014, \& Richards, 2012).

Moreover, engaging in movement activities does not only promote academic performance but also good health and prevention of childhood obesity. Ogden, Lam, and Flegal (2010) contended that there is a prevalence of rapid and gradual increase of children who are overweight and obese worldwide, affecting all socio-economic levels and ethnicities. Thus, the integration of movement and activity as part of the core academic lessons such as Math, Language Arts, and Science was endorsed to address the problem (White House of Task Force on Childhood Obesity, 2010). Sibley and Etnier (2003) suggested that the incorporation of movement and physical activities in the curriculum can positively affect students' academic performance across the different aspect of learning: mentally, emotionally and psychologically.

Greenwood, Horton and Utley, 2002 postulated that students' academic engagement is a primary predictor of academic performance. Academic engagement happens when students make an effort to learn and create connection to the materials given by the teacher. Thus, this study, in which focus is on developing a compendium of kinesthetic activities tailor-fit to promote academic engagement and provide a meaningful experience and genuine well-rounded education to the students in this unprecedented time. 


\section{Methods}

In order to attain the primal thrust of this research, the researcher made use of the quantitative approach, specifically the descriptive research method. The Department of Education, Division of Bohol which consist of 185 public high schools was the locale of this study. A total of 32 printed learning modules in the core academic subjects in junior high school; English, Math, Science, and Social Studies during the first quarter of the S.Y. 2020-2021 was used as sources of data. In order to collect the data, a researcher's matrix tool on kinesthetic approaches (Hands-on Experience, Role Play/Drama, Creative Movements, Songs and Music, and Games and Play) was used. The subject coordinators of the core academic subjects, as considered experts, were asked to evaluate the self-learning modules if there are kinesthetic approaches integrated in the prepared modular distance learning kit using the matrix tool. Data collected through the matrix tool was tabulated, classified, analyzed, and interpreted with the help of frequency, percentage, and ranking. Moreover, descriptive analysis was also used in this study to determine the different integrated kinesthetic approaches into different subject area. The findings of this study was validated by an Educational Program Supervisor in MAPEH and a university PE professor, who are part of the panel.

\section{Results and Discussion}

The first research problem investigated is the extent of integration of the kinesthetic approaches in the modules of the core academic subjects: English, Math, Science, and Social Studies.

Table 1. Extent of Kinesthetic Approaches Integrated in the Core Academic Subjects

\begin{tabular}{|l|c|c|l|}
\hline \multicolumn{1}{|c|}{ English } \\
\hline Kinesthetic Approach es & Frequency & Percent & \multicolumn{1}{c|}{ Extent of Integration } \\
\hline Hands - on Experien ce & 2 & 6.25 & Never/A lmost Never In tegrated \\
Role play / Drama & 0 & 0.00 & Never/A lmost Never Integrated \\
Creative Movements & 0 & 0.00 & Never/A lmost Never Integrated \\
Songs and Music & 1 & 3.13 & Never/A lmost Never Integrated \\
Games / Play & 0 & 0.00 & Never/A lmost Never Integrated \\
Overall Result & 3 & 9.38 & Seldom Integrated
\end{tabular}




\begin{tabular}{|c|c|c|c|}
\hline \multicolumn{4}{|c|}{ Math } \\
\hline Kinesthetic Approaches & Frequency & Percent & Extent of Integration \\
\hline Hands - on Experience & 3 & 9.38 & Seld om Integ rated \\
\hline Role play / Drama & 0 & 0.00 & Never/A lmost Never Integrated \\
\hline Creative Movements & 0 & 0.00 & Never/A lmost Never In tegrated \\
\hline Songs and Music & 0 & 0.00 & Never/A lmost Never In tegrated \\
\hline Games / Play & 0 & 0.00 & Never/A lmost Never In tegrated \\
\hline Ov erall Resu it & 3 & 9.38 & Seld om Integ rated \\
\hline \multicolumn{4}{|c|}{ Science } \\
\hline Kinesthetic Approaches & Frequency & Percent & Extent of Integration \\
\hline Hands - on Experien ce & 7 & 21.88 & Somet imes Integ rated \\
\hline Role play / Drama & 0 & 0.00 & Never/A lmost Never In tegrated \\
\hline Creative Movements & 0 & 0.00 & Never/A lmost Never In tegrated \\
\hline Songs and Music & 0 & 0.00 & Never/A lmost Never In tegrated \\
\hline Games / Play & 0 & 0.00 & Never/A lmost Never In tegrated \\
\hline Overall Resu lt & 7 & 21.88 & Somet imes Integ rated \\
\hline \multicolumn{4}{|c|}{ Social Studies } \\
\hline Kinesthetic Approaches & Frequency & Percent & Extent of Integration \\
\hline Hands - on Experien ce & 5 & 15.63 & Seld om Integ rated \\
\hline Role play / Drama & 1 & 3.13 & Never/A lmost Never In tegrated \\
\hline Creative Movements & 0 & 0.00 & Never/A lmost Never In tegrated \\
\hline Songs and Music & 1 & 3.13 & Never/A lmost Never In tegrated \\
\hline Games / Play & 0 & 0.00 & Never/A lmost Never In tegrated \\
\hline Overall Resu lt & 7 & 21.88 & Somet imes Integ rated \\
\hline \multicolumn{4}{|c|}{ Overall Resu lt } \\
\hline Kinesthetic Approaches & Frequency & Percent & Extent of Integration \\
\hline Hands - on Experien ce & 17 & 13.28 & Seld om Integ rated \\
\hline Role play / Drama & 1 & 0.78 & Never/A lmost Never In tegrated \\
\hline Creative Movements & 0 & 0.00 & Never/A lmost Never In tegrated \\
\hline Songs and Music & 2 & 1.56 & Never/A lmost Never In tegrated \\
\hline Games / Play & 0 & 0.00 & Never/A lmost Never In tegrated \\
\hline Ov erall Resu it & 20 & 15.63 & Seld om Integ rated \\
\hline
\end{tabular}

English. As reflected in Table 1, the extent of kinesthetic approaches integrated in English garnered $9.38 \%$ with an interpretation of "seldom integrated". A closer look at the table would reveal that hands-on experience ranks first with $6.25 \%$ with an interpretation of almost never integrated, songs and music rank second with $3.13 \%$ with an interpretation of almost never integrated while role-play/drama, creative movements, and games/play rank fourth garnered $0.00 \%$ with an interpretation of never integrated. 
The result shows that there was "seldom integrated" of kinesthetic approaches in the Learning Activity Sheets in English. This suggests that students do not actively engage in learning in any form of movement activities, but more on reading and writing activity as it is the nature of this new learning approach. Jensen (2000) argued that active learning is more effective as it reaches a variety of learners, more engaging, and lasts longer as it helps students to remember better rather than sedentary learning. Sitting for long periods may cause behavioral problems which makes students become tired, anxious, and have a decreased level of focus and awareness. Wiles \& Bondi (2007) stated that sitting and being inactive for a long period is not beneficial to the physical and mental performance of the students. Language educators must try to provide students with authentic learning experience and communication. Communication includes the non-verbal aspect which relates to kinesthetic learning. The kinesthetic approach plays a significant role in language learning activities, highlighting the way in which the body communicates and at the same time complements verbal communication.

Math. As seen in Table 1, the extent of kinesthetic approaches integrated in Math garnered 9.38\% with an interpretation of "seldom integrated". It also revealed that hands-on experience ranks first with 9.38\% with an interpretation as seldom integrated while role-playing/drama, creative movements, songs and music, and games/play rank 3.5 which garnered $0.00 \%$ with an interpretation of never integrated.

The data presented above indicates that that there was "seldom integrated" of kinesthetic approaches in the Learning Activity Sheets in Math. This implies that students do not benefit from kinesthetic approaches. Gatelye, Curtis, and Hardaker (2013) suggested that Mathematics is an ideal subject for incorporating movements as it does not take much time to plan active lessons compared to other subjects. Students can benefit more from kinesthetic approaches, especially in mathematical vocabulary. They can use vocabulary manipulations to learn algebra (Thompson \& Rubenstein, 2000).

Mathematics is a pencil and paper-based course with little or non-variants at all. Students have difficulty and less motivated in learning mathematics, much more without the presence of the teacher in this modular distance learning approach. Westerhold (1998) contended that using movement in instruction serves as a motivator for students who are not interested in learning. It allows students to create connections with the course material and the world around them which contributed to increased motivation in learning. Moreover, the integration of movements into classroom lessons can be a potential to increase students' involvement, motivation, and focus (Strean, 2011\& Zimmerman, 2002).

Science. Table 1 also showed the extent of kinesthetic approaches integrated in Science garnered $21.88 \%$ with an interpretation of "sometimes integrated". It also revealed that hands-on experience ranks first with $21.88 \%$ with an interpretation of sometimes integrated while role-play / drama, creative movements, 
songs and music, and games /play rank 3.5 got $0.00 \%$ with an interpretation of never integrated.

The data presented above indicates that that there have been instances where kinesthetic approaches were integrated in the Learning Activity Sheets in Science. The kinesthetic style of teaching and learning has not often been used in instruction even though this mode of learning is the central feature of early learning and known to be the farthest from language (Piaget, 1952).

Science is a hard-to-teach subject especially for young students as abstract concepts is the core of this area (Carin, 1997; Gega \& Peters, 1998). One of the necessary skills for learners to understand science and the world is inquiry. However, despite scientific knowledge and technological advancement, students' academic performance in math and science remains low because of the ineffective science teaching in the educational curriculum (USDOE, 1992; USDOE, 2000a National). This is because of the traditional and ineffective teaching (Goodnough, 2001; Leonard, 2000; UDSE, 2000a; Weld, 2000).

Finn and Mclnnis (2013) claimed that incorporating movements in the traditional science curriculum promotes physical activity and academic performance. Integrating movement in the classroom curriculum has positively influenced the bodies and minds of students, which influence student's ability to perform academically. Lengel and Kuczala (2010) identified connections between cognitive functioning and the integration of movement in the classroom and how they have helped improved student interest, motivation, and attention.

Social Studies. As seen in Table 1, the extent of the kinesthetic approaches integrated in Social Science got $21.88 \%$ with an interpretation of "sometimes integrated". It also revealed that hands-on experience ranks first got $15.63 \%$ with an interpretation of seldom integrated, role play/drama and songs and music place on rank 2.5 garnered $3.13 \%$ with an interpretation of almost never integrated, and creative movements and games/play rank 4.5 generated with $0.00 \%$ with an interpretation of never integrated.

The result shows that there was "sometimes integrated" of kinesthetic approaches in the Learning Activity Sheets in Social Studies. With all the people and dates that need to be remembered, it creates frustration in the students. This sentiment echoed among the middle graders regarding their opinion in Social Studies classes (Gibson, 2012). Students become dissatisfied with the subject and unmotivated to learn. Dwyer (2002, p.267) noted that "when teaching becomes too explicit and lacks sufficient challenge, the learner can "tune out"". Learners will "tune out" unless movements are integrated into instruction time.

Westerhold (1998) contended that using movement in instruction can be an effective way to motivate students for those who are not interested in learning. Kinesthetic teaching and learning contribute to increase motivation as it allows students to create connections between the material and around them. Students are more likely to pay attention and keep the knowledge taught if they are motivated. 
Kinesthetic learning promotes positive attributes, such as increased student participation, motivation, and focuses identified by educators who have incorporated movement into classroom lessons (Strean, 2011; Trudeau \& Shephard, 2008). Schlechty (1997) stressed that teachers should no longer think about how students should be inspired. Instead, teachers in the classroom must understand what motivates particular students and how learning can be better planned to satisfy such diverse interests.

Core Academic Subjects: It can be gleaned in Table 1 that the extent of kinesthetic approaches integrated into the core academic subjects garnered $15.63 \%$ with an interpretation of "seldom integrated". A closer look at the table revealed that hands-on experience ranks first garnered $13.28 \%$ with an interpretation of seldom integrated, songs and music rank second got $1.56 \%$ with an interpretation of almost never integrated, role play/drama rank third got $0.78 \%$ with an interpretation of almost never integrated, creative movements and games and play rank 4.5 with $0.00 \%$ with an interpretation of never integrated.

This means that that there was "seldom integrated" of kinesthetic approaches in the Learning Activity Sheets into the core academic subjects: English, Math, Science, and Social Studies. Chenfeld (2004) argued that the use of movement, music, and kinesthetic experience are the most effective way to learn, understand, absorb, and know. Moreover, Chenfeld suggested that educators should integrate movement in all aspects of the curriculum as it can be connected to any thought, lesson, and concept. Despite the educational reforms in the global education system which aims to provide quality education and promote lifelong learning opportunities, the vision of providing a complete and quality education among the basic education students remains a challenge. Students' overall academic performance has not been impressive and continued to deteriorate.

Furthermore, among the 79 participating countries, Filipino learners placed 79 and near last in Mathematics and Science (Program for International Student Assessment of the Organization for Economic Co-operation and Development, 2019). Perhaps, it is time to take into consideration the integration of kinesthetic approaches into classroom instruction. Movement is easily accessible to all teachers and a very powerful tool in helping to teach academics successfully. Richards (2012) suggested that students who had received instruction with kinesthetic approach performed better that students who had not and have higher academic achievements (Pollatscheck \& Hagen, 1996).

The second research problem investigated the preferred kinesthetic approaches integrated into the Learning Activity Sheets of the core academic subjects. This includes hands-on experience, role play/drama, creative movements, songs and music, and games/play. 
Table 2. Preferred Kinesthetic Approaches Integrated into the Core Academic Subjects

\begin{tabular}{|c|c|c|c|}
\hline \multicolumn{4}{|c|}{ Integration of Hands- on Experience in the Core Academic Subjects } \\
\hline \multicolumn{4}{|c|}{$\mathrm{N}=32$} \\
\hline Core Subject & Frequency & Percent & Extent of Integration \\
\hline English & 2 & 6.25 & Never/Almost Never Integrated \\
\hline Math & 3 & 9.38 & Seldom Integrated \\
\hline Science & 7 & 21.88 & Sometimes Integrated \\
\hline Social Studies & 5 & 15.63 & Seldom Integrated \\
\hline Overall Result & 17 & 10.625 & Seldom Integrated \\
\hline \multicolumn{4}{|c|}{ Integration of Role Play/Drama in the Core Academic Subjects } \\
\hline \multicolumn{4}{|c|}{$\mathrm{N}=32$} \\
\hline Core Subject & Frequency & Percent & Extent of Integration \\
\hline English & $\mathrm{O}$ & 0.00 & Never/Almost Never Integrated \\
\hline Math & o & 0.00 & Never/Almost N ever Integrated \\
\hline Science & O & 0.00 & Never/Almost Never Integrated \\
\hline Social Studies & 1 & 3.13 & Never/Almost Never Integrated \\
\hline Overall Result & 1 & 0.625 & Never/Almost Never Integrated \\
\hline \multicolumn{4}{|c|}{ Integration of Creative Movements in the Core Academic Subjects } \\
\hline \multicolumn{4}{|c|}{$\mathbf{N}=32$} \\
\hline Core Subject & Frequency & Percent & Extent of Integration \\
\hline English & O & 0.00 & Never/Almost Never Integrated \\
\hline Math & O & 0.00 & Never/Almost Never Integrated \\
\hline Science & O & 0.00 & Never/Almost Never Integrated \\
\hline Social Studies & O & 0.00 & Never/Almost Never Integrated \\
\hline Overall Result & o & o & Never/Almost Never Integrated \\
\hline \multicolumn{4}{|c|}{ Integration of Songs and Music in the Core Academic Subjects } \\
\hline \multicolumn{4}{|c|}{$\mathrm{N}=32$} \\
\hline Core Subject & Frequency & Percent & Extent of Integration \\
\hline English & 1 & 3.13 & Never/Almost Never Integrated \\
\hline Math & o & 0.00 & Never/Almost N ever Integrated \\
\hline Science & O & 0.00 & Never/Almost Never Integrated \\
\hline Social Studies & 1 & 3.13 & Never/Almost Never Integrated \\
\hline Overall Result & 2 & 1.25 & Never/Almost Never Integrated \\
\hline \multicolumn{4}{|c|}{ Integration of Games/Play in the Core Academic Subjects } \\
\hline \multicolumn{4}{|c|}{$\mathrm{N}=32$} \\
\hline Core Subject & Frequency & Percent & Extent of Integration \\
\hline English & O & 0.00 & Never/Almost Never Integrated \\
\hline Math & o & 0.00 & Never/Almost Never Integrated \\
\hline Science & O & 0.00 & Never/Almost Never Integrated \\
\hline Social Studies & o & 0.00 & Never/A lmost N ever Integrated \\
\hline Overall Result & $\mathrm{O}$ & $\mathrm{O}$ & Never/Almost Never Integrated \\
\hline
\end{tabular}




\begin{tabular}{|l|c|c|c|}
\hline \multicolumn{4}{|c|}{ PREF ERRED KINESTHETIC APPROACHES INTEGRATED } \\
\hline \multicolumn{4}{|c|}{ IN THE MODULES OF THE CORE ACADEMIC SUBJECTS } \\
\hline \multicolumn{4}{|c|}{$\mathrm{N}=32$} \\
\hline Core Subject & Frequency & Percent & Extent of Integration \\
\hline English & 3 & 9.38 & Seldom Integrated \\
Math & 3 & 9.38 & Seldom Integrated \\
Science & 7 & 21.88 & Sometimes Integrated \\
Social Studies & 7 & 21.88 & Sometimes Integrated \\
Overall Result & 20 & 12.5 & Seldom Integrated
\end{tabular}

Hands-on Experience. As reflected in Table 2, the extent of integration of the hands-on experience in the core academic subjects got $10.625 \%$ with an interpretation of "seldom integrated". It also revealed that the integration of hands-on experience in Science rank first garnered $21.88 \%$ with an interpretation of sometimes integrated, Social Studies rank second got $15.63 \%$ with an interpretation of seldom integrated, Math rank third with $9.38 \%$ with an interpretation of seldom integrated, English rank fourth got $6.25 \%$ with an interpretation of almost never integrated.

The data presented above implies that there was "seldom integrated" of hands-on experience into the core academic subjects. According to Strahan et al. (2012), recent brain research revealed that learning is about actively seeing relations between abstraction and realistic implementation. This means that students must have an authentic experience for them to connect with real-world situations. A hands-on experience is a kinesthetic approach which involves object manipulation and real-word experience in which students control objects with their hands (Armstrong, 2000). This kinesthetic approach requires the active involvement of students in creating their questions, planning their experiments, and performing their experiments to solve real-world problems (Selco, Bruno \& Chan, 2012). Hands-on experience allows students to understand the purpose of their learning as they take on the authentic part of works and to become more actively involved in their learning experiences and ignites thinking.

Role Play/Drama. As seen in Table 2, the extent of integration of role-play/drama in the core academic subjects generated $0.625 \%$ with an interpretation of "almost never integrated". A closer look at the table would reveal that Social Studies rank first in the integration role-play/drama got 3.13\% with an interpretation of almost never integrated, English, Math and Science rank third got $0.00 \%$ with an interpretation of never integrated.

This means that that there was "almost never integrated" of role play/drama into the core academic subjects. Crumbley, Smith, and Smith (1998) suggested that drama and role-playing facilitate learning and provide enthusiasm to practice knowledge and work together. The drama-based instruction methods include interactive games, improvisation, and role-playing which provide an authentic and more interactive and 
stimulating learning experience for students. Bonwell and Eison (1991) stated that role play is an effective way to engage students in the classroom where students play or move their body to explain the lecture point, or taking out students on experimental trips to go through the lecture for more clarifications.

Creative Movements. As reflected in Table 2, the extent of integration of creative movements in the core academic subjects, namely: English, Math, Science, and Social Studies which yielded $0.00 \%$ with an interpretation of "never integrated". The data presented above implies that that there was no integration of creative movements into the core academic subjects. Becker (2013) contended that cognitive learning is enhanced by dancing.

The creative movement integrates spontaneously created body movements to express an idea or experience. The true essence of living fully while learning is imagination. This creative thinking process provides a boundless benefit both for teachers and students. It facilitates personal exploration, the use of imagination, original thoughts and ideas, the enjoyment of the process of turning work into 'play' art, being present at the moment, collecting new information, and connecting past and current experiences and knowledge (Williams, K., 2011). Furthermore, Sousa (2006) claimed that creative movement evokes an emotional response that helps the brain retains information and can remember it practically. The integration of creative movements in learning is necessary so that comprehension and retention will take place. Thus, help students to perform better academically.

Songs and Music. Table 2 also showed the extent of songs and music integrated into the core academic subjects garnered $1.25 \%$ with an interpretation of "almost never integrated". It also revealed that the integration of songs and music in English and Social studies rank 1.5 got $3.13 \%$ with an interpretation of almost never integrated, Math and Science rank 3.5 got $0.00 \%$ with an interpretation of never integrated.

The data presented above indicates that that there was "almost never integrated" of songs and music into the core academic subjects. Music integration is a purposeful merging of musical learning and academic content. There is a plethora of studies which focuses on various music-centered techniques to aid comprehension in different subject matter such as mathematics, social studies, and science, wherein the results transcend pencil and paper. Rhythmic movement programs are viewed as energetic and enjoyable practices (Zachopoulou, Derri, Chatzopoulos, \& Ellinoudis, 2003). It also improved the concentration of pupils which affects students' academic performance (Juntunen, Perkiö, \& Simola-Isaksson, 2010; Fross, 2000). Shin (2006) agreed that songs are useful teaching strategies that can enhance and sustain students' motivation.

Games/play. As reflected in Table 2, the extent of integration of the games and play in the core academic subjects got $0.00 \%$ with an interpretation of "never integrated". It also revealed that the extent of games and play in all core academic subjects, namely: English, Math, Science, and Social Studies got $0.00 \%$ 
with an interpretation of never integrated.

This means that there was no integration of games/play into all core academic subjects. Games/play provides fun and engaging activities for students to enhance student learning. Play is not a hindrance to academic learning, nor is its lazy teaching. Play lays the foundation for the development of vital social and emotional awareness and skills. Via play, children learn to forge relationships with others, to share, discuss, and settle disputes, as well as to learn the skills of self-advocacy (UNICEF, Learning Through Play 2018). Social interactions encourage children to learn through authentic experiences.

Preferred Kinesthetic Approaches. It can be gleaned in Table 2 that the preferred kinesthetic approaches integrated into the modules of the core academic subjects generated with $12.5 \%$ with an interpretation of "seldom integrated". It also revealed the Science and Social studies garnered $21.88 \%$ with an interpretation of sometimes integrated respectively, English and Math got 9.38\% with an interpretation of seldom integrated.

This means that there are no preferred kinesthetic approaches integrated into the self-learning modules of the core academic subjects: English, Math, Science, and Social Studies. Integrating movement or kinesthetic approaches are aimed at promoting and increasing student engagement yet this style of teaching and learning is not often used in the classroom.

The integration of movement in the classroom is not something that is being tested on a standardized test in any state, nor something that is necessary for teachers. It is, rather, a form of teaching that can help improve children's academic ability. However, the integration of movement in the classroom instruction should not take over academia. Instead, the movement needs to be incorporated into the curriculum as a means of complementing and improving learning in the various subject areas.

Strean (2011) postulated that the integration of movement into the classroom lessons have been reported positive attitudes among the students such as increased student participation, interest, and concentration. Moreover, students who received movement instruction in the classroom performed better in academics than those who had not (Richards, 2012).

The third research problem investigated the parts of the module that the kinesthetic approaches are being integrated into each core academic subject. The self-learning modules used by the Department of Education, Division of Bohol contain three parts: concept note, activity, and enhancement activity. 


Grade $10 \quad \begin{gathered}\text { Kinesthetic } \\ \text { Approach }\end{gathered}$ Part of the Module

Week 7

ACTIVITY 1.

Directions:

Search the song entitled" IMAGINE" by John Lennon with this Songs and Music

Enhancement url,

www.you tube.com/watch?V=RwUGSYDKUxU

Play and listen to the song.

While listening, list down 5 words which you think relate much to the term building ties and also related to the title. You can use your dictionary to find their meaning for more understanding.

ACTIVITY 2. Answer the questions below. (3pts. Each). What positive traits and values are mentioned in the song? What is Lennon's vision of peace? Give examples.

What is your vision of peace? Is it the same with the author? Explain.

ACTIVITY 3. Show your interpretation of the song through a drawing. You can have your drawing at the back. Make your output colorful and attractive. (20 pts).

Hands-on

Experience

\section{Week 8}

\section{ACTIVITY 2}

Directions:

1. Start now making your photo essay. Think about the most difficult challenge/problem in your personal life like poverty, shyness or you can choose from our previous myth characters, how they deal their challenges in life.

2. Since visuals are the keys to the meaning of your work, you are going to collect pictures, photos, and pictures from magazines, newspapers, print ads, commercial ads or journals, drawings, video segment or illustrations that show or relate to the theme of the message of your chosen challenges in life.

3. Display these pictures, drawings, illustrations or video segments. Use visuals/graphics to highlight the incidents and examples which are used as supports and evidences for impact. See to it that you can explain the significance of each illustration. Your opinion (personal feelings or beliefs) about the characters and the incidents must support the drawing or the illustration.

4. Establish the connection between and among your visuals, texts and main idea.

5. Provide a catchy and meaningful TITLE to your photo essay.

6. Edit, refine and polish your work.

7. Use the following rubric as your guide.

(For the teacher, you may formulate your own rubric.) 
English. The kinesthetic approaches integrated into the self-learning modules in English are handson experience and songs and music. These kinesthetic approaches came together in Week 7 of the Grade 10 module which allows students to demonstrate their learning. Students were asked to listen to the music entitled" IMAGINE" by John Lennon. While listening, students listed down at least five words that were related to the topic "Building Ties". This kinesthetic activity was integrated into the activity part of the module. After which, students were tasked to present their interpretation through a drawing which was integrated into the enhancement activity.

In Week 8 of the module, hands-on experience was integrated into the activity part. Students were tasked to collect pictures, photos, and pictures from magazines, newspapers, print ads, commercial ads or journals, drawings which illustrate or relate to the theme about their chosen topic in making their photo essay.

\section{Integrated Kinesthetic Approaches in Math}

\begin{tabular}{lcc}
\hline Grade 7 (Week 8) & $\begin{array}{c}\text { Kinesthetic } \\
\text { Approach }\end{array}$ & $\begin{array}{l}\text { Parts of the } \\
\text { Module }\end{array}$ \\
\hline $\begin{array}{l}\text { Direction: Draw a number line and arrange the real } \\
\text { numbers from least to greatest. Use a dot to represent the }\end{array}$ & $\begin{array}{c}\text { Hands-on } \\
\text { Experience }\end{array}$ & Activity \\
number. & & \\
$\begin{array}{l}\text { 1. }-8,-10,3,-6,7 \\
\text { 2. } 0.25,-0.5,-14,12,-34,0\end{array}$ & \\
3. $\sqrt{2},-\sqrt{4},-12 /, 2$. & \\
4. $-3.62, \sqrt{ } 3, \pi,-98 /, 0.4$ &
\end{tabular}

Grade 8 (Week 6)

Exercises A. Graph each linear equation that passes through the given pair of points. (Provide another sheet for your answers.)

1.) $(1,2)$ and $(3,4) 2).(-1,2)$ and $(0,1)$

Hands-on Activity

B. Graph each linear equation whose $\mathrm{x}$-intercept and $\mathrm{y}$ intercept $\mathrm{b}$ are given below.

1.) $a=2$ and $b=12$.) $a=-2$ and $b=$

\section{Grade 9 (Week 7)}

Exercise: Sketch the graph of the following quadratic functions by following the given steps above.

1. $\mathrm{y}=\mathrm{x}$

Experience

$2-2 x-2$

Hands-on

Activity

2. $y=x$

$2+4 x+8$ 
Math. The only kinesthetic activity integrated into the self-learning modules in Math is a hands-on experience which is all integrated into the activity part. In Week 8 of the Grade 7 module, students drew number lines using dots to represent a number and arrange the real numbers from least to greatest. Meanwhile, for Week 6 of the Grade 8 module, students created graphs to show each linear equation that passes through the given pair of points. Lastly, for the Week 7 of the Grade 9 module, students created sketches to show the graph of the different quadratic functions by following the steps in graphing a quadratic function.

\section{Integrated Kinesthetic Approaches in Science}

\begin{tabular}{ll}
\hline Grade 7 & Kinesthetic \\
Approach & $\begin{array}{l}\text { Parts of the } \\
\text { Module }\end{array}$
\end{tabular}

\section{Week 3}

Materials Needed: food labels of 3 different products

(sprite, bear brand, silver swan)

Hands-on

Activity

Procedure:

Refer to the labels of different food products you have.

List down the compounds in the product label and the constituent elements.

Exercise: Compounds and their constituent elements written in the food labels

\begin{tabular}{|l|l|l|}
\hline Food Product & Compound & $\begin{array}{l}\text { Constituent } \\
\text { Element }\end{array}$ \\
\hline 1. & & \\
\hline 2. & & \\
\hline 3. & & \\
\hline
\end{tabular}

\section{Week 5}

Exercise:

My Unknown Sample: Substance or Mixture?

Materials Needed

Hands-on Activity
Experience

Procedure

Design a procedure to identify if the unknown sample is a mixture or a substance. Limit the materials that you are going to use with what is already available. Follow the Steps in Scientific Method:

Identify or define the problem. State your problem in a question form.

Gather enough information about the problem and study them.

Formulate the hypothesis. Make a guess. State the possible answer to the problem. 
Test the hypothesis. Conduct experiment to prove your hypothesis or tentative answer.

Make a conclusion. Explain the results of your experiment.

Verify the conclusion. Share results, compare findings and repeat if necessary

\section{Week 6}

Materials: As indicated in the table column -1 (c-1) below

Hands-on

Activity

Experience

Procedures:

Make a data table similar to the one below: Answer c-2 using your predictions.

Put one cup of water in each sample materials one at a time.

Use the teaspoon to stir and dissolve as much of each sample as possible.

Use different cups, teaspoons, and cloths to filter for each sample.

Describe the mixture that resulted after mixing and filtering, note also the phases.

Write your observations/ answers in columns c-3 to c-6 respectively

\begin{tabular}{|l|l|l|l|l|l|}
\hline $\begin{array}{l}\text { c-1 } \\
\text { mample } \\
\begin{array}{l}1 \\
\text { tablespoon } \\
\text { each) }\end{array}\end{array}$ & $\begin{array}{l}\text { Will } \\
\text { dissolve } \\
\text { in one } \\
\text { cup } \\
\text { water? } \\
\text { (yes or } \\
\text { no) }\end{array}$ & $\begin{array}{l}\text { Appearance } \\
\text { (uniform/ } \\
\text { non- } \\
\text { uniform) }\end{array}$ & $\begin{array}{l}\text { c-4 } \\
\text { Number } \\
\text { of } \\
\text { Phases } \\
\text { (One- } \\
\text { homo, } \\
\text { more } \\
\text { than } \\
\text { one- } \\
\text { hetero) }\end{array}$ & $\begin{array}{l}\text { Can be } \\
\text { separated } \\
\text { by } \\
\text { filtration? } \\
\text { (yes / no) }\end{array}$ & $\begin{array}{l}\text { Solution } \\
\text { / Not } \\
\text { Solution }\end{array}$ \\
\end{tabular}

Week 7

Materials:

Granules or uncrushed table salt coffee or powdered milk 8 
Crushed table salt or iodized salt $40 \mathrm{~mL}$ oil (4 tablespoon) $5 \mathrm{~mL} \mathrm{(1}$ teaspoon) alcohol

Procedure:

The Effect of Particle Size

For container/cup A: Place 1/2 teaspoon of granule or uncrushed table salt (rock salt)

For container/cup B: Place 1/2 teaspoon crushed table salt or iodized table salt.

2. Add 5 tablespoon $(50 \mathrm{~mL})$ of water into each container/cup.

3. Take note of the time it takes for the salt to dissolve in water.

Q1. Which of the two containers where salt dissolves faster?

Q2. Which of the two containers where salt dissolves slower?

\section{B. The Effect of Stirring}

1. Spread equal amount, $1 / 2$ teaspoon rock salt at the bottom of the two containers.

2. In container/cup A, slowly add 5 tablespoons $(50 \mathrm{~mL})$ of water then using the spoon stir the contents. Take note the time it takes the rock salt to dissolve in water.

3. In container/cup B, slowly add 5 tablespoons $(50 \mathrm{~mL})$ of water and let it stand (undisturbed). Take note the time it takes the rock salt to dissolve in water.

Q3. Which of the two containers where salt dissolves faster?

Q4. Which of the two containers where salt dissolves slower?

C. The Effect of Temperature

1. Spread equal amount, $1 / 2$ coffee or powdered milk at the bottom of the two containers.

2. For container/cup A: Add 5 tablespoon $(50 \mathrm{~mL})$ of hot water into the container. Take note of the time it takes the coffee or milk to dissolve in hot water.

3. In container/cup B: Add 5 tablespoon $(50 \mathrm{~mL})$ of cold or tap water (water from the faucet). Take of the time it takes the coffee or milk to dissolve in cold or tap water.

Q5. Which of the two containers where coffee or powdered milk dissolves faster?

Q6. Which of the two containers where coffee or powdered milk dissolves slower?

D. The Nature of Solute and Solvent

1. In container/cup A, put 2 tablespoons $(20 \mathrm{~mL})$ of oil then add $1 / 2$ teaspoon $(5 \mathrm{~mL})$ alcohol then shake. Take note what happens.

2. In container/cup B, put 2 tablespoons $(20 \mathrm{~mL})$ of oil then add $1 / 2$ teaspoon $(5 \mathrm{~mL})$ of water then shake. Take note what happens. 
Q7. Which of the two containers where the two liquids dissolve with each other?

Q8. Which of the two containers where the two liquids do not dissolve with each other?

Grade 8 (Week 4)

\section{Activities/Exercises:}

Together with your brother or sister or any family member:

Hands-on

Experience

Activity

1. Stand at opposite sides of an open field.

2 Measure the distance between these two spots.

3. Ask your brother or sister or any family member to hold two blocks of wood high up in the air so that you can see it from the other side

4. Ask your brother or sister to hit the two blocks together hard enough for you to hear the bang.

5. Press the start button on your stopwatch when you see the blocks bang together.

6. Press the stop button on your stopwatch when you hear the banging blocks.

7. Compute for the speed of sound by dividing the distance between the two sides that you and your brother or sister is standing on by the elapsed time.

8. Repeat this process at three different times of the day such as 9:00 am, 1:00 pm and 5:00 pm.

9. Make at least three trials each time you do the activity and get the average of the three.

1. What happens to the speed of sound when you hear it in a field at different times of the day?

2. Solve for the speed of sound at 9:00 AM if temperature is at time is $28^{\circ} \mathrm{C}$.

3. Explain how different temperatures affect the speed of sound.

Grade 9 (Week 6)

Through a process called photosynthesis, plants use energy in sunlight to turn a gas called carbon dioxide and water into glucose (sugar). Plants then use this sugar to grow. At the same time, plants produce a gas called oxygen as a by-product, which is needed for us to breathe.

Activity:

1. How do plants make their own food?

2. Make a graphic organizer showing the process of food making by plants.
Hands-on

Activity

Experience 
Grade 10 (Week 5)

Activity:

Millions of years ago, land masses (which were once connected) moved away from each other by divergence. If this event continues for millions

Hands-on

Activity of years, what do you think will be the effect on the crust? Illustrate your understanding of the effect of landmasses when moved away from each other by divergence on the crust.

Science. There were seven hands-on experiences integrated into the self-learning modules in science. All of these kinesthetic activities were integrated into the activity part which allows students to complete a task.

For the Grade 7, Week 3 of the module talked about the matter of labels, students collect different products such as sprite, bear brand, silver swan. Using the product label, they listed down different compounds and the constituent elements. Week 5 discussed unknown samples. Students were tasked to design a procedure to identify if the unknown sample is a mixture of a substance. They experimented to prove their hypothesis or a tentative answer. The Week 6 module focused on the properties of the solution. Students investigated the properties of unsaturated or saturated solutions by adding one cup of water to each sample material one at a time. Then, they described the mixture that resulted after mixing and filtering and also noted the phases. Lastly, Week 7 allowed students to determine the factor affecting solubility. Students perform an experiment that demonstrates the solubility of a solution.

Meanwhile, in the Grade 8, Week 4 of the self-learning modules focused on explaining how temperature affects the speed of sound. With the use of block woods and stopwatch, students performed the activity with the assistance of any members of the family.

Also, for the Week 6 of the Grade 9 self-learning modules, students demonstrated their understanding of the process of food making by plants by making a graphic organizer while for the Week 5 of the Grade 10 self-learning modules, students were allowed to illustrate their understanding of the effect of landmasses when moved away from each other by divergence on the crust. 


\section{Integrated Kinesthetic Approaches in Social Studies}

$\begin{array}{cc}\text { Kinesthetic } & \text { Parts of the } \\ \text { Approach } & \text { Module }\end{array}$

Pagsasanay: Gumawa ng talahanayan ng mga yamang likas (likas na kagandahan) na matatagpuan sa ating probinsya/lugar.

Hands-on Activity
Experience

\begin{tabular}{|l|l|l|l|l|}
\hline $\begin{array}{l}\text { Yamang } \\
\text { likas }\end{array}$ & Lugar & Uri & Kapakinabangan & Pangangalaga \\
\hline $\begin{array}{l}\text { Tingkawob } \\
\text { River }\end{array}$ & $\begin{array}{l}\text { Calinginan } \\
\text { Norte, } \\
\text { Sevilla, } \\
\text { Bohol }\end{array}$ & $\begin{array}{l}\text { Yamang } \\
\text { tubig }\end{array}$ & $\begin{array}{l}\text { dahil sa turismo } \\
\text { nabigyan ng } \\
\text { hanapbuhay ang } \\
\text { mga taong } \\
\text { naninirahan } \\
\text { malapit sa ilog }\end{array}$ & $\begin{array}{l}\text { Huwag } \\
\text { magtapon ng } \\
\text { mga basura sa } \\
\text { ilog para } \\
\text { manatili ang } \\
\text { likas na } \\
\text { kalinisan at } \\
\text { kagandahan ni } \\
\text { to. }\end{array}$ \\
\hline
\end{tabular}

\section{Grade 8}

\section{Week 3}

\section{Activity 1}

Hands-on

Activity

Panuto: Gumuhit ng isang simbolo na may kaugnayan sa iba’t ibang saklaw sa pag-aaral ng heograpiyang pantao. Pumili lamang ng isang saklaw.

\section{Week 4}

Activity 1. Ilarawan o ipakita sa pamamagitan ng pagguhit kung paano napaunlad ang pamumuhay ng mga sinaunang tao sa panahong paleolitiko at mesolitiko. Lagyan ng kulay ang inyong guhit. (20 pts.)

Hands-on Activity
Experience


Grade 9

Week 3

Activity 1

1. Batay sa mga natutunan ninyo sa mga nakaraang aralin, kayo ay gagawa ng

Songs and Enhancement isang malikhaing Gawain para ipahayag ninyo ang kahalagahan ng ekonomiks sa

Music

Activity

pang-araw-araw

na pamumuhay ng bawat pamilya at ng lipunan.

Hands-on

Experience

2. Ang mga sumusunod ay maaari ninyong pagpilian na malikhain sa Gawain.

Pero kung mayroong kayong naisip na mas magandang paraan sa pagpapahayag ng inyong saloobin sa kahalagan ng ekonomiks "Please feel free to use it"

Role play /

$\begin{array}{ll}* \text { Tula } & * \text { Poster } \\ * \text { Spoken Poetry } & * \text { Story Telling } \\ * \text { Collage } & * \text { Jingle }\end{array}$

Week 5

Activity: 1

\section{PAGSASANAY}

1. Bakit mahalaga ang produksyon?

Hands-on

Activity

2. Gumawa ng isang halimbawa na nagpapakita ng antas ng produksyon. Iguhit

Experience ang inyong paglalarawan o maaari din na gumamit ng larawan sa pagpapakita sa antas ng produksyon.

Social Studies. The self-learning modules in Social Studies have integrated hands-on experience, role play/drama, and songs and music. These kinesthetic approaches allowed students to demonstrate their learning and provide teachers a varied and creative way to assess students learning.

In Week 5 of the Grade 7 module, students cut and collected pictures of different natural resources. They also created tables of the different natural resources that can be found in their respective provinces/localities.

For Grade 8, Week 3 modules allowed students to illustrate their understanding through drawing on how the way of life of the ancient people was developed during the Paleolithic and Mesolithic periods. In week 4, students were tasked to draw a symbol that is related to the various fields of study of human geography.

In Week 3 of the Grade 9 module, students were tasked to do creative work (spoken poetry, collage, and jingle) to demonstrate their understanding of the importance of economics to the everyday living of every family and society. Rubrics were used to assess students' output. Lastly, Week 5 of the Grade 9 module, students created a drawing to illustrate their understanding of the different levels of production.

Most kinesthetic approaches were integrated in the activity part of the module of the core academic 
subjects. It is where concepts were put to test and validation of understanding begins. It also served as an avenue to provide an authentic experience where students actively engaged and relate to real-world situations while answering the modules.

\section{Conclusion}

The integration of kinesthetic approaches in the self-learning modules was never considered or given priority. Some of the instructional materials do not promote active engagement to the students. Teacherswriters of the modules are not Physical Education teachers. They have less background in the kinesthetic approach and most likely had minimal experience in movement instruction during their pre-service teaching.

Moreover, due to the sudden shift of educational system, there was no enough time to carefully plan the self-learning modules. Teachers-writers were not given proper training in the preparation of making the module. The sample template did not include kinesthetic approaches in which the teachers-writers simply followed the given sample. On that account the integration of kinesthetic approaches is limited due to limited ideas.

\section{Recommendations}

The self-learning modules should be enhanced and should promote active engagement to the students to keep their interest in learning and connect to the learning process in different ways. Students learn and retain information effectively by doing and creating.

The compendium of kinesthetic approaches must be integrated into the self-learning modules to promote physical and academic engagement which helps students improve their physical activity levels, wellbeing, and academic performance.

\section{References}

DepEd Bohol D.M. No. 188, S. 2020.

Lengel, T., \& Kuczala, M. (2010). The kinesthetic classroom: Teaching and learning through movement. Thousand Oaks, CA: Corwin Press.

Barker, J. E., Semenov, A. D., Michaelson, L., Provan, L. S., Snyder, H. R., \& Munakata, Y. (2014). Lessstructured time in children's daily lives predicts self-directed executive. Frontiers in Psychology, 5, 593 doi: $10.3389 /$ fpsyg. 2014.00593

Richards, T. (2012). Using kinesthetic activities to teach ptolemaic and Copernican retrograde motion. Science and Education, 21(6), 899910.

Ogden, R., Carroll, M., Curtin, L., McDowell, M., Tabak, C., \& Flegal, K. (2010). American Medical Prevalence of overweight and obesity in the United States (2007-2008). The Journal of the Association, 303(3), 242-9. 
White House Task Force on Childhood Obesity (2010). Solving the Problem of Childhood Obesity within a Generation. Report to the President. http://www.letsmove.gov/sites/letsmove. gov/files/TaskForce_on_Childhood_Obesity_May2010_FullReport.pdf.

Sibley, B., and J. Etnier. 2003. "The Relationship between Physical Activity and Cognition in Children: A Meta-analysis.” Pediatric Exercise Science 15(3): 243-256.

Greenwood, C. R., Horton, B. T., \& Utley, C. A. (2002). Academic Engagement: Current Perspectives on Research and Practice. School Psychology Review, 31, 328-349.

Jensen, E. (2000). Learning with the body in mind: The scientific basis for energizers, movement, play, games, and physical education. San Diego, CA: The Brain Store, Inc.

Wiles, J., \& Bondi, J. (2007). Curriculum development: A guide to practice (7th ed.). Upper Saddle River, NJ: Prentice Hall.

Gately, P., Curtis, C., \& Hardaker, R. (2013). An evaluation in UK schools of a classroom based physical activity programme - TAKE 10 ! $®$ : A qualitative analysis of the teachers' perspective.

Thompson \& Rubenstein (2000). Learning Mathematics Vocabulary: Potential Pitfalls and Instructional Strategies. Mathematics Teacher 97(7). DOI: 10.5951/MT.93.7.0568

Westerhold, S.P. (1998). Bodies and brains in motion. Gifted Child Today Magazine, 21, 16-19. Retrieved from Elise Fulginiti (2009). Using movement and kinesthetic learning to teach academics in a fourthgrade classroom.

Strean, W. B. (2011). Creating student engagement? HMM: Teaching and learning with humor, music, and movement. Creative Education, 2(3), 189-192.

Zimmerman, B. J. (2002). Becoming a Self-Regulated Learner: An Overview. Theory into Practice, 41, 6470. http://dx.doi.org/10.1207/s15430421tip4102_2

Piaget, J. (1952). The Origins of Intelligence in Children. New York: International Universities Press, 1952.

Carin, A. A. (1997). Teaching science through discovery. Englewood, NJ: Prentice- Hall.

U.S. Department of Education (USDOE). (1992). The Condition of Education National Center for Education Statistics. Washington, D.C.

U.S. Department of Education. (USDOE) (2000a). Before it's Too Late: A Report to the Nation from the National Commission on Mathematics and Science Teaching for the $21^{\text {st }}$ Century. (2000b). Education Publication Center. U.S. Department of Education. Washington D.C

Goodnough, K. (2001). Multiple intelligences theory: A framework for personalizing science curricula. School science and Mathematics, 101 (4), 180-193.

Finn, K. E., \& McInnis, K. (2013). Integrating Movement and Science to Promote Physical Activity and Academic Performance in Middle School Children. International Journal of Science Education and Civic Engagement, 5(1), 12-16.

Gibson, S. (2012) 'Why do we learn this stuff'? Students' views on the purpose of social studies, Canadian Social Studies, 45(1), pp. 43-58

Dwyer, B. M. (2002). Training strategies for the twenty-first century: Using recent research on learning to enhance training. Innovations in Education and Teaching International, 39(4), 265-270. Retrieved October 12, 2020, from http://www.tandf.co.uk/journals.

Trudeau, F., Shephard, R.J. (2008). Physical education, school physical activity, School Sports and academic performance. Int J Behav Nutr Phys Act 5, 10 https://doi.org/10.1186/1479-5868-5-10

Schlechty, P. (1997). Inventing better schools: An action plan for educational reform. San Francisco, CA: Jossey-Bass.

Chenfeld, M. (2004). Education is a moving experience: Get movin! YC Young Children, 59 (4), 56-57.

Pollatscheck, J. \& Hagen, F. (1996). Smarter, healthier, happier. International Health, Racquet, and Sports Club Association Booklet, Boston, MA.

Strahan, D. (2008). Successful teachers develop academic momentum with reluctant students. Middle School Journal, 39(5), 4-12. Retrieved from https://bit.ly/3609V0v 
Armstrong, T. (2000). Multiple Intelligences in the Classroom (2 nd ed.). VA: Association for Supervision and Curriculum Development. Retrieved from https://bit.ly/35RSdOd

Selco, J., Bruno, M., \& Chan, S. (2012). Students Doing Chemistry: A Hand-On Experience for K 12. Journal of Chemical Education, 89, 206-210.

Crumbley, D. L., Smith, K. T., \& Smith, L. M. (1998). Teaching note educational novels and student role playing: a teaching note. Accounting Education, 7(2), 183-191. https://bit.ly/3oSZu7O

Bonwell, C. \& Eison, J. (1991). Active Learning: Creating Excitement in the Classroom (George Washington Univ, Washington, DC).

Becker, K. (2013). Dancing Through the School Day: How Dance Catapults Learning in Elementary Education. Journal of Physical Education, Recreation and Dance, vol. 84, no. 3, 2013, pp. 6-8. doi:10.1080/07303084.2013.763665.

Williams, K. (2011). Creativity Notes. Creativity is.

Sousa, D. A. (2006). How the brain learns. Thousand Oaks, Calif: Corwin Press.

Zachopoulou, E., Derri, V., Chatzopoulos, D., \& Ellinoudis, T. (2003). Application of Orff and Dalcroze activities in preschool children: Do they affect the level of rhythmic ability? The Physical Educator, 60(2), 50-56.

Juntunen, Perkiö, \& Simola-Isaksson (2010). Effects of a Music-Movement Program in Elementary School Physical Education Classes on Pupils' Motor Skills.

Shin, J.K. (2006) "Ten Helpful Ideas for Teaching English to Young Learners." English Teaching Forum, 44 (2): $2-7,13$.

UNICEF Learning through play. Published by UNICEF Education Section, Programme Division 3 United Nations Plaza New York, NY 10017, USA. https://uni.cf/32b0kD7 